\title{
The peculiarities of legal regulation of entrepreneurship in the agro-industrial complex during emergencies
}

\author{
Oksana Shmaliy ${ }^{1, *}$, Olga Grechkina $^{1}$, Vitaly Vanin $^{2}$, Lesia Dushakova $^{3}$, and Natalia \\ Jagaryan $^{4}$ \\ ${ }^{1}$ The Russian Presidential Academy of National Economy and Public Administration, Vernadsky \\ Ave., 84, Moscow, 119571, Russia \\ ${ }^{2}$ Russian State University of Justice, Moscow, Novocheryomushkinskaya str., 117418, Russia \\ ${ }^{3}$ South Russian Institute of Management of the Russian Presidential Academy of National Economy \\ and Public Administration, Pushkinskaya str., 70, Rostov-on-Don, 344002, Russia \\ ${ }^{4}$ Southern Federal University, M. Gorky str., 88, 344002, Rostov-on-Don, Russia
}

\begin{abstract}
The research findings concerning legal regulation of entrepreneurship in the agro-industrial complex during emergencies (covid19 pandemic) have been presented. After analyzing a number of reference sources it has been concluded, that there is a lack of scientific and methodological solutions for the legal support of the agro-industrial complex functioning and development. The general assessment of the situation in the agro-industrial complex in terms of emerging stress -factors has been made. The focus on emergency regulation has been demonstrated in the sphere of administrative legislature on agribusiness, as well as its interconnection with the key acts of the national strategic planning. (National Security Strategy of the Russian Federation and the Doctrine of Food Security of the Russian Federation). The conclusions have been made about the necessity to improve the legislature in the sphere under study, by means of adopting new regulations and amending the current ones in order to form the legal foundation and universal mechanisms of extraordinary regulation as applied to agribusiness.
\end{abstract}

\section{Introduction}

The new social and economic reality, which took place in 2020 due to Covid -19 pandemic, implies the necessity of timely and effective respond to challenges and threats connected with new extraordinary factors and events, which can 't help posing a threat to any country.

Public and local government authorities should be properly prepared to respond intensively and urgently to any extreme situations not only in terms of organization, but also in terms of legal support of their activity, which would allow in the shortest possible time, with sufficient reliability to confront any negative factors intruding in the society`s balanced life, to minimize losses and harm, which inevitably become the consequences of any emergency situation, especially a prolonged one. Accurate legal support of the actions of those who provide the introduction and maintenance of the emergency regime will help to

\footnotetext{
* Corresponding author: vlad_dushakov@mail.ru
} 
struggle effectively with sudden unforeseen factors and to ensure the enjoyment of human and citizens` rights and liberties.

It especially concerns the agro-industrial complex as one of the basic branches of Russian economy. Obviously, the companies in this sector have proved vulnerable to such a development of events, which resulted in considerable losses, mostly for small and mediumsized agricultural businesses. At the same time the negative consequences of restrictive measures undertaken by governmental authorities have been partly offset due to the specific nature of agro-industrial production, aimed at meeting one of the fundamental human needs - the need in food. Besides, sustainable functioning and development of the agro-industrial complex are one of the key factors of national security [National Security Strategy of the Russian Federation: Edict of the Russian Federation President, 31.12.2015 № 683 // http://www.pravo.gov.ru, 31.12.2015], in particular, providing food security [1].

And in this regard, it should be noted that the statistical data on monitoring food security carried out by the Ministry of Agriculture of Russia show not so significant, but generally confident fluctuations in the agricultural market for the main product positions. In particular, this statement can be demonstrated by the dynamics of prices for certain types of products.

Table 1. Average grain prices according to the Food Security Monitoring and Forecasting System of the Ministry of Agriculture of Russia (RUB/ton, excluding VAT)

(https://mcx.gov.ru/upload/iblock/9cc/9cc95eadc0d60895e4d2389ed087516d.do).

\begin{tabular}{|c|c|c|c|c|c|c|c|}
\hline & CFD & SFD & NCFD & VFD & UFD & SibFD & FEFD \\
\hline \multicolumn{8}{|c|}{ as of February 27. 2020} \\
\hline $\begin{array}{l}\text { wheat } \\
\text { grade } \\
3\end{array}$ & $\begin{array}{c}11600 \\
(+0.1 \%)\end{array}$ & $\begin{array}{c}11287 \\
(-0.3 \%)\end{array}$ & $\begin{array}{c}11562 \\
(0.0 \%)\end{array}$ & $\begin{array}{c}11197 \\
(+0.1 \%)\end{array}$ & $\begin{array}{c}11461 \\
(-0.4 \%)\end{array}$ & $\begin{array}{c}10669 \\
(-0.8 \%)\end{array}$ & \\
\hline $\begin{array}{l}\text { wheat } \\
\text { grade } \\
4\end{array}$ & $\begin{array}{c}11415 \\
(+3.2 \%)\end{array}$ & $\begin{array}{c}10903 \\
(-0.5 \%)\end{array}$ & $\begin{array}{c}10448 \\
(0.0 \%)\end{array}$ & $\begin{array}{c}10613 \\
(+0.5 \%)\end{array}$ & $\begin{array}{c}10200 \\
(-0.9 \%)\end{array}$ & $\begin{array}{c}9312 \\
(-0.3 \%)\end{array}$ & $\begin{array}{c}8532 \\
(0.0 \%)\end{array}$ \\
\hline $\begin{array}{l}\text { wheat } \\
\text { grade } \\
5\end{array}$ & $\begin{array}{c}10626 \\
(+1.3 \%)\end{array}$ & $\begin{array}{c}9754 \\
(-1.3 \%)\end{array}$ & $\begin{array}{c}9346 \\
(0.0 \%)\end{array}$ & $\begin{array}{c}9952 \\
(+0.9 \%)\end{array}$ & $\begin{array}{c}9730 \\
(+1.3 \%)\end{array}$ & $\begin{array}{c}9215 \\
(-0.1 \%)\end{array}$ & $\begin{array}{c}8149 \\
(0.0 \%)\end{array}$ \\
\hline barley & $\begin{array}{c}8991 \\
(+1.9 \%) \\
\end{array}$ & $\begin{array}{c}9232 \\
(-0.8 \%) \\
\end{array}$ & $\begin{array}{c}10000 \\
(0.0 \%)\end{array}$ & $\begin{array}{c}8596 \\
(-1.0 \%) \\
\end{array}$ & $\begin{array}{c}7977 \\
(+6.4 \%) \\
\end{array}$ & $\begin{array}{c}8006 \\
(-0.9 \%) \\
\end{array}$ & $\begin{array}{c}9409 \\
(0.0 \%)\end{array}$ \\
\hline corn & $\begin{array}{c}9338 \\
(+2.2 \%)\end{array}$ & $\begin{array}{c}10016 \\
(+1.0 \%)\end{array}$ & $\begin{array}{c}9500 \\
(0.0 \%)\end{array}$ & $\begin{array}{c}8855 \\
(+0.2 \%)\end{array}$ & & & \\
\hline \multicolumn{8}{|c|}{ as of April 2. 2020} \\
\hline $\begin{array}{l}\text { wheat } \\
\text { grade } \\
3\end{array}$ & $\begin{array}{c}12388 \\
(+8.8 \%)\end{array}$ & $\begin{array}{c}12798 \\
(+3.0 \%)\end{array}$ & $\begin{array}{c}13424 \\
(+6.5 \%)\end{array}$ & $\begin{array}{c}11456 \\
(+1.0 \%)\end{array}$ & $\begin{array}{c}11940 \\
(+1.5 \%)\end{array}$ & $\begin{array}{c}11223 \\
(+3.8 \%)\end{array}$ & \\
\hline $\begin{array}{l}\text { wheat } \\
\text { grade } \\
4\end{array}$ & $\begin{array}{c}11667 \\
(+4.3 \%)\end{array}$ & $\begin{array}{c}12590 \\
(+5.4 \%)\end{array}$ & $\begin{array}{c}12691 \\
(+6.2 \%)\end{array}$ & $\begin{array}{c}10813 \\
(+1.2 \%)\end{array}$ & $\begin{array}{c}10575 \\
(0.0 \%)\end{array}$ & $\begin{array}{c}10680 \\
(+6.1 \%)\end{array}$ & $\begin{array}{c}8539 \\
(+0.8 \%)\end{array}$ \\
\hline $\begin{array}{l}\text { wheat } \\
\text { grade } \\
5\end{array}$ & $\begin{array}{c}11012 \\
(+2.2 \%)\end{array}$ & $\begin{array}{c}10744 \\
(+2.7 \%)\end{array}$ & $\begin{array}{c}11189 \\
(+5.8 \%)\end{array}$ & $\begin{array}{c}10438 \\
(+1.1 \%)\end{array}$ & $\begin{array}{c}9610 \\
(0.0 \%)\end{array}$ & $\begin{array}{c}10090 \\
(+7.0 \%)\end{array}$ & $\begin{array}{c}9445 \\
(+0.4 \%)\end{array}$ \\
\hline barley & $\begin{array}{c}9066 \\
(-2.9 \%)\end{array}$ & $\begin{array}{c}9805 \\
(+1.8 \%)\end{array}$ & $\begin{array}{c}10345 \\
(+0.4 \%)\end{array}$ & $\begin{array}{c}8661 \\
(-1.1 \%) \\
\end{array}$ & $\begin{array}{c}7500 \\
(0.0 \%)\end{array}$ & $\begin{array}{c}8772 \\
(+6.4 \%)\end{array}$ & \\
\hline rye & & $\begin{array}{c}15000 \\
(+7.9 \%)\end{array}$ & & $\begin{array}{c}9909 \\
(0.0 \%)\end{array}$ & & $\begin{array}{c}10000 \\
(-3.3 \%)\end{array}$ & \\
\hline corn & $\begin{array}{c}9214 \\
(-1.8 \%) \\
\end{array}$ & $\begin{array}{c}10286 \\
(+0.7 \%) \\
\end{array}$ & $\begin{array}{c}10000 \\
(+2.6 \%) \\
\end{array}$ & $\begin{array}{c}8530 \\
(-4.0 \%)\end{array}$ & & & \\
\hline
\end{tabular}




\begin{tabular}{|c|c|c|c|c|c|c|c|}
\hline \multicolumn{8}{|c|}{ as of May 14. 2020} \\
\hline $\begin{array}{l}\text { wheat } \\
\text { grade } \\
3 \\
\end{array}$ & $\begin{array}{c}13850 \\
(+4.8 \%)\end{array}$ & $\begin{array}{c}13159 \\
(+0.2 \%)\end{array}$ & $\begin{array}{l}14300 \\
(0.0 \%)\end{array}$ & $\begin{array}{c}12348 \\
(+1.7 \%)\end{array}$ & $\begin{array}{c}12560 \\
(+2.1 \%)\end{array}$ & $\begin{array}{c}11846 \\
(+0.5 \%)\end{array}$ & \\
\hline $\begin{array}{l}\text { wheat } \\
\text { grade } \\
4\end{array}$ & $\begin{array}{c}13207 \\
(+4.5 \%)\end{array}$ & $\begin{array}{c}13045 \\
(+0.2 \%)\end{array}$ & $\begin{array}{c}14100 \\
(0.0 \%)\end{array}$ & $\begin{array}{c}11777 \\
(-0.2 \%)\end{array}$ & & $\begin{array}{c}11192 \\
(+0.7 \%)\end{array}$ & \\
\hline $\begin{array}{l}\text { wheat } \\
\text { grade } \\
5\end{array}$ & $\begin{array}{c}11549 \\
(+2.4 \%)\end{array}$ & $\begin{array}{l}11239 \\
(0.0 \%)\end{array}$ & $\begin{array}{c}10843 \\
(-2.0 \%)\end{array}$ & $\begin{array}{c}11267 \\
(-1.5 \%)\end{array}$ & $\begin{array}{c}11082 \\
(-2.9 \%)\end{array}$ & $\begin{array}{c}10557 \\
(-2.7 \%)\end{array}$ & $\begin{array}{c}9091 \\
(0.0 \%)\end{array}$ \\
\hline barley & $\begin{array}{c}9344 \\
(-5.3 \%) \\
\end{array}$ & $\begin{array}{c}9776 \\
(+0.2 \%) \\
\end{array}$ & $\begin{array}{c}10133 \\
(0.0 \%) \\
\end{array}$ & $\begin{array}{c}9364 \\
(+4.6 \%) \\
\end{array}$ & $\begin{array}{c}8750 \\
(-6.7 \%) \\
\end{array}$ & $\begin{array}{c}9114 \\
(+2.3 \%) \\
\end{array}$ & $\begin{array}{r}9773 \\
(0.0 \%) \\
\end{array}$ \\
\hline rye & & $\begin{array}{l}13500 \\
(0.0 \%) \\
\end{array}$ & & $\begin{array}{l}12000 \\
(0.0 \%)\end{array}$ & & & \\
\hline corn & $\begin{array}{c}9912 \\
(-2.6 \%)\end{array}$ & $\begin{array}{c}10413 \\
(0.0 \%)\end{array}$ & $\begin{array}{c}10250 \\
(+1.5 \%)\end{array}$ & $\begin{array}{c}9553 \\
(+0.7 \%)\end{array}$ & & & \\
\hline \multicolumn{8}{|c|}{ as of September 24. 2020} \\
\hline $\begin{array}{l}\text { wheat } \\
\text { grade } \\
3\end{array}$ & $\begin{array}{c}12298 \\
(-1.9 \%)\end{array}$ & $\begin{array}{c}13657 \\
(+4.5 \%)\end{array}$ & $\begin{array}{c}12974 \\
(+2.4 \%)\end{array}$ & $\begin{array}{c}11787 \\
(-0.7 \%)\end{array}$ & $\begin{array}{c}13727 \\
(+4.8 \%)\end{array}$ & $\begin{array}{c}11952 \\
(+1.0 \%)\end{array}$ & \\
\hline $\begin{array}{l}\text { wheat } \\
\text { grade } \\
4\end{array}$ & $\begin{array}{c}11152 \\
(-1.3 \%)\end{array}$ & $\begin{array}{c}13110 \\
(+3.8 \%)\end{array}$ & $\begin{array}{c}1190 \\
(0.0 \%)\end{array}$ & $\begin{array}{c}10810 \\
(+0.3 \%)\end{array}$ & 12825 & $\begin{array}{c}10970 \\
(+0.3 \%)\end{array}$ & \\
\hline $\begin{array}{l}\text { wheat } \\
\text { grade } \\
5\end{array}$ & $\begin{array}{c}10767 \\
(+1.8 \%)\end{array}$ & $\begin{array}{c}12128 \\
(+3.8 \%)\end{array}$ & $\begin{array}{c}11323 \\
(+5.9 \%)\end{array}$ & $\begin{array}{c}9644 \\
(+1.1 \%)\end{array}$ & $\begin{array}{c}11244 \\
(+3.0 \%)\end{array}$ & $\begin{array}{c}10380 \\
(-1.9 \%)\end{array}$ & $\begin{array}{l}10284 \\
(0.0 \%)\end{array}$ \\
\hline barley & $\begin{array}{c}9542 \\
(+1.6 \%) \\
\end{array}$ & $\begin{array}{c}11178 \\
(+4.5 \%) \\
\end{array}$ & $\begin{array}{c}10741 \\
(0.0 \%) \\
\end{array}$ & $\begin{array}{c}8859 \\
(+0.9 \%) \\
\end{array}$ & $\begin{array}{c}10814 \\
(+0.6 \%) \\
\end{array}$ & $\begin{array}{c}8604 \\
(+1.9 \%) \\
\end{array}$ & $\begin{array}{l}10100 \\
(0.0 \%) \\
\end{array}$ \\
\hline rye & & $\begin{array}{c}13179 \\
(-4.5 \%) \\
\end{array}$ & & $\begin{array}{c}8812 \\
(+0.5 \%) \\
\end{array}$ & & $\begin{array}{c}10414 \\
(-1.5 \%) \\
\end{array}$ & \\
\hline corn & $\begin{array}{c}10890 \\
(+4.7 \%) \\
\end{array}$ & $\begin{array}{c}10615 \\
(+0.3 \%)\end{array}$ & $\begin{array}{c}10000 \\
(+2.0 \%)\end{array}$ & & & & \\
\hline \multicolumn{8}{|c|}{ as of December 3.2020} \\
\hline $\begin{array}{l}\text { wheat } \\
\text { grade } \\
3\end{array}$ & $\begin{array}{c}15178 \\
(+2.6 \%)\end{array}$ & $\begin{array}{c}16998 \\
(-0.3 \%)\end{array}$ & $\begin{array}{c}15388 \\
(-1.4 \%)\end{array}$ & $\begin{array}{c}13667 \\
(-0.3 \%)\end{array}$ & $\begin{array}{c}14186 \\
(-2.8 \%)\end{array}$ & $\begin{array}{c}13034 \\
(+0.4 \%)\end{array}$ & \\
\hline $\begin{array}{l}\text { wheat } \\
\text { grade } \\
4\end{array}$ & $\begin{array}{c}14122 \\
(+2.4 \%)\end{array}$ & $\begin{array}{c}16501 \\
(+1.0 \%)\end{array}$ & $\begin{array}{l}13937 \\
(0.0 \%)\end{array}$ & $\begin{array}{c}12597 \\
(+0.4 \%)\end{array}$ & $\begin{array}{c}13173 \\
(-1.2 \%)\end{array}$ & $\begin{array}{c}12024 \\
(+1.3 \%)\end{array}$ & \\
\hline $\begin{array}{l}\text { wheat } \\
\text { grade } \\
5\end{array}$ & $\begin{array}{c}12272 \\
(+1.0 \%)\end{array}$ & $\begin{array}{c}15153 \\
(+1.0 \%)\end{array}$ & $\begin{array}{c}12883 \\
(+1.8 \%)\end{array}$ & $\begin{array}{c}11465 \\
(+1.4 \%)\end{array}$ & $\begin{array}{c}12256 \\
(-0.9 \%)\end{array}$ & $\begin{array}{c}11607 \\
(+1.8 \%)\end{array}$ & $\begin{array}{l}12142 \\
(0.0 \%)\end{array}$ \\
\hline barley & $\begin{array}{c}11350 \\
(+0.6 \%) \\
\end{array}$ & $\begin{array}{c}13312 \\
(+2.2 \%) \\
\end{array}$ & $\begin{array}{c}11700 \\
(-1.4 \%) \\
\end{array}$ & $\begin{array}{c}9991 \\
(+1.0 \%) \\
\end{array}$ & $\begin{array}{c}11585 \\
(-1.2 \%) \\
\end{array}$ & $\begin{array}{c}9823 \\
(+1.6 \%) \\
\end{array}$ & $\begin{array}{l}10300 \\
(0.0 \%) \\
\end{array}$ \\
\hline rye & $\begin{array}{c}10000 \\
(0.0 \%)\end{array}$ & $\begin{array}{c}12054 \\
(0.0 \%) \\
\end{array}$ & & $\begin{array}{c}9336 \\
(+0.7 \%) \\
\end{array}$ & & $\begin{array}{c}11591 \\
(0.0 \%) \\
\end{array}$ & \\
\hline corn & $\begin{array}{c}13133 \\
(+3.0 \%) \\
\end{array}$ & $\begin{array}{c}13169 \\
(0.0 \%) \\
\end{array}$ & $\begin{array}{c}10750 \\
(0.0 \%) \\
\end{array}$ & $\begin{array}{l}13630 \\
(0.0 \%) \\
\end{array}$ & & & \\
\hline
\end{tabular}


Table 2. Dynamics of milk and dairy prices in the Food Security Monitoring and Forecasting System of the Ministry of Agriculture of Russia, RUB $/ \mathrm{kg}$

(https://mcx.gov.ru/upload/iblock/9cc/9cc95eadc0d60895e4d2389ed087516d.do.

\begin{tabular}{|c|c|c|c|c|c|c|c|}
\hline & 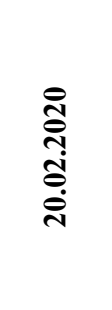 & 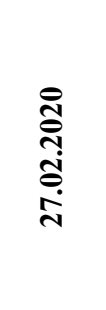 & 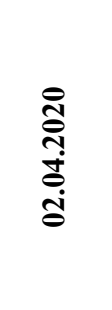 & 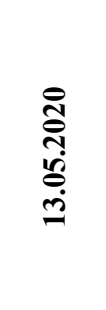 & 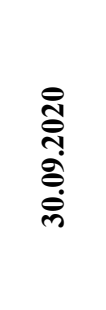 & 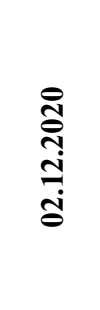 & 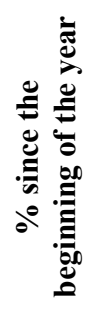 \\
\hline $\begin{array}{l}\text { Raw milk } \\
\text { (excluding } \\
\text { VAT) }\end{array}$ & 25.77 & 25.78 & 25.73 & 25.32 & 25.10 & 26.18 & 102.6 \\
\hline $\begin{array}{l}\text { Pasteurized } \\
\text { milk } \\
\text { (including } \\
\text { VAT) }\end{array}$ & 45.03 & 45.28 & 45.23 & 45.41 & 45.27 & 46.07 & 104.2 \\
\hline $\begin{array}{l}\begin{array}{l}\text { Butter } \\
\text { (including } \\
\text { VAT) }\end{array} \\
\end{array}$ & 502.01 & 501.26 & 505.80 & 498.62 & 496.30 & 502.95 & 103.5 \\
\hline $\begin{array}{l}\text { Cheeses } \\
\text { (including } \\
\text { VAT) }\end{array}$ & 370.57 & 372.77 & 368.32 & 367.80 & 373.35 & 377.88 & 101.9 \\
\hline
\end{tabular}

In both scientific literature and mass media the idea that our life will no longer be the same is commonly spread, and we have to adjust ourselves to new social and economic reality. The idea is obviously worth taking into consideration. And in this connection it is very important to create the necessary legal instruments and resources with a high degree of responsiveness and adaptability, which will allow to ensure sufficiently sustainable development of the agro-industrial complex during emergencies.

One should admit, that there are very few studies aimed at evaluating and analyzing organizational and legal (administrative and legal) support of entrepreneurship in the agroindustrial complex (one can mention certain works by Minina E.L [2], Kalinina L.E [3], Eliseeva V.S [4], etc), besides, these studies have not had practical application to the sphere in question. However, it should be noted, that the studies of this kind are beginning to appear (Karataeva O.G., Zubkova O.V. [5]).

The emphasis is mainly put on the legal support of the system of organizational and financial measures for keeping the agribusiness afloat.

The review of global scientific publications proves that no reference sources provide the solution to the task, set in the given paper. Thus, one can speak about the lack of fundamental researches in the field of organizational and legal support of entrepreneurship in the agroindustrial complex, on the whole and during emergencies, which makes the topic of the given paper relevant. Consequently, the main objective of the given research is to analyze theoretical and methodological, organizational and legal support of the entrepreneurial activity in the agro-industrial complex during emergencies at the current stage of the country`s developmen, as well as to make corresponding suggestions about upgrading current legislature.

\section{Materials and Methods}

This research uses general and specific scientific methods of cognition, aimed at achieving 
the goals of the study and solving the tasks within the field of the study.

As general scientific methods we used, in particular, such methods as systemic analysis and synthesis of scientific knowledge, dialectic cognition, logical, statistical, comparative, modeling methods, etc. And as specific scientific methods formal- juridical, comparativejuridical, systemic-dogmatic interpretation of the current legislature, etc. were used.

The empirical base of the research included regulations of the existing national legislature, including goal-setting acts, federal laws and acts of the Russian Federation President and the Russian Federation government regulations

\section{Results}

\subsection{The general review of the agro-industrial complex during the emergency situation due to Covid-19 pandemic}

It should be noted, first and foremost, that, on the whole, the agro-industrial complex is undergoing this emergency situation quite smoothly, without considerable shocks and turmoils. As it was mentioned above, such a situation can be explained - the focus on the basic human needs in food, which determines better conditions for the branch in overcoming the negative phenomena, however, this negative impact can not be excluded and it implies the necessity to reinforce the risk-oriented component of the agro-industrial complex development, including the formation of the legal model of confronting risks in the agroindustrial complex.

The risk-factors, which the agricultural business is subject to, are on the whole the same, and they can as well be applied to other types of entrepreneurship:

- depreciation

(excludes the objective opportunity of financing the development; reduces financial and material supplies, to some extent sequestrates certain expenditures, which can be considered unnecessary for the current business processes; leads to higher currency costs, the amount of which depends on the complexity and time-span of the production cycle, which is extremely relevant for the agricultural business);

- logistics

(the break of production linkages, which can be total and absolutely unforeseen, as the limitations practice demonstrate);

- the barriers to market entry due to reallocation of resources and products amid the pandemic stress;

- the changes in the consumer market of agricultural products

(food inflation; contraction of demand; purchasing power is more inclined to low-cost product).

The above mentioned factors consequently result in lower financial sustainability and change the investment climate in the agro-industrial complex. $[6,7,8]$ The possibility of reevaluating the approach to finance can't be ruled out, primarily, in terms of project regulation, as the latter is aimed at developing, not overcoming the force majeure and excludes the flexibility in using resources.

\subsection{The administrative legislature on agribusiness is focused on emergency regulation}

Generally speaking, governmental regulation in the sphere of agro-industrial complex is of strategic importance, as it is a crucial element of the common system ensuring food security 
and food independence. [Doctrine on Food Security of the Russian Federation: Edict of the Russian Federation President, 21.01.2020 № 20 // http://www.pravo.gov.ru, 21.01.2020]

In this context governmental regulation is meant to ensure the implementation of state agricultural policy and is based on the combination of economic, legal and organizational measures, etc. In this respect project regulation is actively used: several governmental programs on agro-industrial complex are currently being implemented («Comprehensive development of agricultural areas», «The development of fishery complex», The Governmental program of agricultural development and regulation of markets of agricultural products, raw materials and food, Federal scientific and technical program of agricultural development for the period of 2017 - 2025)

The governmental agricultural policy as a legal category is embedded into the whole architectonics of the legal structure of social and economic policy, but at the same time it has its specific features in goal-setting, range of subjects, comprehensive measures, resource provision, accompanied by a body of regulations of public and legal character, which are considerably represented by the acts of administrative legislature.

The current administrative and legal regulation of entrepreneurship in the agro-industrial complex, as a part of the whole system of governmental regulation, includes a considerable amount of regulatory legal acts. Particularly, these are the acts of federal legislature:

- federal laws

(of general character: The Federal Law of 29.12.2006 № 264-FZ «On the development of Agriculture»; The Federal Law of 25.07.2011 № 260-FZ «On governmental support of agricultural insurance and amendments to the Federal Law «On the development of Agriculture»;

concerning certain segments of the agro-industrial complex: The Federal Law of 03.08.1995 № 123-FZ «On livestock breeding»; The Law of RF of 14.05.1993 № 4973-1 «On grain»;

concerning certain aspects of practical implementation of agribusiness: The Federal Law of 08.12.2003 № 164-FZ «On the basics of governmental regulation of foreign trade activities», The Federal Law of 26.07.2006 № 135-FZ «On the protection of Competition», The Federal Law of 31.07.2020 № 248-FZ «On governmental control (supervision) and municipal control in the Russian Federation», The Federal Law of 31.07.2020 № 247-FZ «On Mandatory Requirements in the Russian Federation», etc.);

- presidential edicts and edicts of the Government of the Russian Federation

(the latter prevail, due to the specific nature of authority of the government of the Russian Federation in this sphere of social and economic relations);

- acts of departmental norm-setting, primarily, Ministry of the Russian Federation.

In view of the fact, that a common range of issues for the Russian Federation and its subjects is constitutionally mandated, the regulation is conducted within the framework of regional legislature; wherein it is also possible, that a range of issues refers solely to the subjects of the Russian Federation.

It also should be noted, that at its core current regulation is aimed at the sustainable development of agricultural relations, which is basically peculiar for the national legal system and derives from its fundamental features of regulatory sustainability.

At the same time the situation is rapidly changing, and we are facing the factors, which nowadays can be eliminated only «in a manual mode». That is exactly what we are currently witnessing, watching how the subjects of government administration are attempting to stabilize the situation by means of introducing anti-crisis measure of organizational and financial support (leasing and credit benefits, subsidies, certain costs reimbursement, a compensation of some part of expenses, etc.), which collectively can hardly be considered as a comprehensive model of legal regulation of the entrepreneurial activity in the agroindustrial complex during emergencies. 
Indeed, it is rather challenging to form the universal mechanisms of extraordinary regulation, but they are quite possible and should be used, especially in reference to the agroindustrial complex.

\section{Discussion}

First of all, one should say, that the legal structure of the governmental regulation of the entrepreneurial activity in the agro-industrial complex during emergencies represents an amalgam of regulatory forms and measures, through which governments can influence this sphere of social relations, and which constitute a corresponding legal framework.

Yet, in specialized reference sources the very notion of governmental regulation of entrepreneurial activity in the agro-industrial complex is rather vaguely interpreted, and the question about the admissibility and extent of governmental interference into this field of economic activity still remains disputable. The presence of the emergency factors stipulates the appropriate specifics of using particular legal forms and means in accordance with the objectives of the emergency regulation. Therefore, it seems, that the general goal of the governmental regulation of the entrepreneurial activity in the agro-industrial complex during emergencies consists of providing rational agriculture, implementation and protection of public interests in the field of food security, food independence and national security.

In order to achieve this goal, as it appears, one should create a comprehensive regulatory model, which is, on the one hand, aimed at providing incremental sustainable development of the agro-industrial complex in general and agribusiness in particular: on the other hand, it should contain the legal basics of responding to stress-factors and emergency events, that is a so-called legal «portfolio» of risk management, which corresponds with the Doctrine of food securit.

In this connection, it seems appropriate:

- to get the legal clarification of the governmental regulation of the entrepreneurial activity in the agro-industrial complex, as this notion makes the foundation for forming the general model of such a regulation, including the emergency regulation. The notion, which was coined in reference to commercial activity, can serve as the basic one. (The Federal Law of 28.12.2009 № 381-FZ «On the basics of governmental regulation of commercial activity in the Russian Federation», which encompasses agribusiness as well). We can also take into consideration the notion of governmental regulation of agro-industrial production, which at the time was legally determined (The Federal Law of 14.07. 1997 № 100-FZ «On governmental regulation of agro-industrial production», it is null and void);

- to develop further the conceptual framework. Presently, a kind of imbalance can be noticed in the use of legislative terminology and definitions, in particular, the Federal law of 29.12.2006 № 264-FZ «On the development of agriculture» uses such terms as agriculture, agricultural production, governmental agrarian policy, etc, whereas the areas of the agrarian policy concern the agro-industrial complex, the definition of which is not given, though, firstly, it is quite obvious, that the scope of its notion doesn't coincide with the one of agricultural production, and, secondly, the notion of agrarian policy is not sufficiently determined in the context of general usage of terminology;

- in the context of the problem, which is being put forward, the notion of governmental agrarian policy requires regulatory specification, in particular, defining its goals. According to the Law on agriculture, the agrarian policy implies sustainable development of agriculture and rural areas. The law maker suggests expanding the notion of sustainability, but at the same time uses a combination of evaluative views (stable development, efficiency boosting, rational use). Such an approach excludes the possibility of regulatory position in respect of defining the emergency situation in the agro-industrial complex. Moreover, the existing regulations do not provide the opportunity of identifying the emergency situation with regard 
to the object being under the negative exposure (the agro-industrial complex or agriculture);

- to make the digitalization of the agro-industrial complex a priority, as one of the instruments helping to reduce and manage risks. Presently, the Law on agriculture doesn't contain any provisions on digitalization and end-to-end digital systems. On top of that, the subjects of the Russian Federation can actively develop and implement the acts of strategic planning in the sphere of digitalization of the agro-industrial complex, taking into account the separation of powers and the subjects within the range of issues in the agrarian spheren; [9-16]]

- to shift the emphasis in the legal regulation of the agro-industrial complex towards state protectionism and to ensure sustainable supply patterns: the implementation of major investment projects involving the government, with the guarantee of support in case of any emergency situation; governmental support of production and financial chains, at least, regarding strategic organizations of the agro-industrial complex, which means distributing the part of risks to the government (with regard to financing major producers, limiting guarantees, and so); [17-18]

- to develop agricultural insurance with the support of government, including protection in case of emergency situations;

- to diversify activities in the agro-industrial complex (financial, manufacturing, industry-specific) by means of actually developing the agricultural production according to the type of products and distribution channels and respective types of business activity ( rural /agrarian tourism, service industry, etc).

\section{Conclusions}

In general, the legal regulation of the entrepreneurial activity during emergencies should be considered as one of the key spheres of governmental influence on economic relations, which contribute to the national security of the Russian Federation.

This kind of legal regulation should be comprehensive, adjustable to any emergency situation, cyclical in the process of the strategic planning and modeling of an organization and developing agrarian entrepreneurship. It should be supported by reliable forms and resources and be based on organizational cooperation of the subjects of public administration both on the federal and subfederal levels of organization of power, the international regulators' requirements should also be taken into account.

\section{Acknowledgements}

The study was carried out as part of a scientific project № AAAA-A21-121012190170-7 «Organizational and legal support of emergency legal regimes at the current stage of state development»

\section{References}

1. I.V. Loginova, I.F. Kuz'Minov, E.E. Khabirova, Biotekhnologiya 34 (5), 7-11 (2018), DOI: $10.21519 / 0234-2758-2018-34-5-7-11$

2. E.L. Minina, Journal of Russian Law 6, 134 - 144 (2017) doi: 10.12737/article_59240612b42d52.36179719

3. L.E. Kalinina, Tourism: law and economy 3, 9 - 11 (2016)

4. V.S. Eliseev, Lex russica 6, 103 - 118 (2016)

5. O.G. Karataeva, O.V. Zubkova, Education and Law 4, $432-437$ (2020) DOI: 


\section{$10.24411 / 2076-1503-2020-10468$}

6. I. Ganenko, Agroinvester 5 (2020) https://www.agroinvestor.ru/analytics/article/33642apk-pod-vliyaniem-stress-faktory-2020-goda-mogut-otritsatelno-skazatsya-ne-tolkona-agrariyakh-no-i/

7. E.A. Kapoguzov, R.I. Chupin, M.S. Kharlamova, Terra Economicus 16(2), 122-139 (2018) DOI: 10.23683/2073-6606-2018-16-2-122-139.

8. S.A. Shokri, A. Arkhipov, O. Belokrylova, Y. Filonenko, Mir Rossii 26(2), 82-102 (2017)

9. N.A. Kasavina, Epistemology and Philosophy of Science 56 (4), 251-259 (2020) DOI: DOI: $10.5840 /$ eps201956480

10. I.V. Naumov, J.V. Dubrovskaya, E.V. Kozonogova, Economy of Region 16(3), 896910 (2020) DOI: DOI: 10.17059/ ekon.reg. 2020-3-17

11. O.V. Shmaliy, L.A. Dushakova, Problems of economics and legal practice 15(5), 301306 (2019)

12. I.D. Yagofarova, State power and local self-government 11, 11-15 (2019)

13. N. Johns, Observer Research Foundation (2015) https://www.orfonline.org/wpcontent/uploads/2015/12/SR_06.pdf

14. S.B. Ognivtsev, International Agricultural Journal 2 (368), 77 - 80 (2019)

15. A.V. Kurdyumov, Economics, labor, management in agriculture 3(47), 67 - 72 (2019)

16. M. Belikova, Lex and Law 8, 26 - 30 (2018)

17. I.V. Ryzhov, International Scientific Research 1(26), 189 - 197 (2016)

18. A.A. Afanasyev, State power and local self-government 5, 3 - 7 (2014) 